\title{
PARTICULAR ISSUES OF THE CONFORMITY OF THE USC-2000 COORDINATE SYSTEM TO THE LAND LEGISLATION
}

\author{
Avramchuk B., Ph.D. \\ Institute of Land Management of the National Academy of Agrarian Sciences of Ukraine, \\ e-mail:avramchuk.bogdan@gmail.com \\ Patiyuk $\boldsymbol{O}$., postgraduate student ${ }^{l}$ \\ National University of Life and Environmental Sciences of Ukraine, \\ e-mail: o.patiyuk@gmail.com
}

The coordinate basis for the implementation of land management works is the State Geodetic Reference System of the USC-2000 coordinates. However, as practice of land management shows, public information from the State Land Cadastre is reflected in the coordinate system of 1963 (SC-63).

In this case, in most cases, the recalculation of areas between the above-mentioned coordinate systems leads to a change in the area of land.

Therefore, it is important to highlight some issues regarding the use of the USC-2000 coordinate system with the current land laws that may arise when used in conjunction with the SC63, namely the possible excess of the rules for free remittance. land plots to citizens in the transition to a single state coordinate system.

To investigate such distortions, the authors designed three model land plots in the coordinate system SC-63 in the maximum allowable area in accordance with the norms of free transfer for the maintenance of personal from the eagle economy (2,0000 ha) for the construction and maintenance of a residential building, commercial buildings and structures (private plot) in villages (0,2500 hectares) and for gardening respectively (0,1200 hectares). Subsequently, using the standard features of the licensed Digitals software, the coordinates of each plot of land from the SC-63 system in the USC-2000 were recalculated within the three selected administrative units .

For the purpose of visual representation, the coordinates of the first point of the listed land plots in USC-2000 were given the coordinates of the first point of land in the system SC-63 .

Changes or distortions in squares, lines or angles are obvious when moving from one coordinate system to another if they are based on ellipsoid referents with different parameters.

However, it should be noted that the compliance of the USC-2000 with the land legislation, and in particular the excess of the area of established norms for the free transfer of land plots to citizens in modern conditions in the transition to a legally established single frame of reference USC-2000, requires further consideration and resolution, for example, by clarification legislation .

\footnotetext{
${ }^{1}$ Supervisor - Ph.D., Assoc. Prof. Martyn A.
} 
Keywords: Land Code, norms of free privatization, reference system of coordinates, SC63, USC-2000.

Problem statement. According to the Ukrainian Law USC-2000 in the course of carrying out land management works [7], which states that the State Geodetic reference system of coordinates USC-2000 is an indisputable basis for the implementation of land management works.

However, as practice of land management shows, public information from the State Land Cadastre is reflected in the coordinate system of 1963 (SC-63).

In this case, in most cases, the recalculation of areas between the abovementioned coordinate systems leads to a change in the area of land.

Analysis of recent research and publications. In Ukraine, the regulation of topographic and geodetic works during land management is carried out by a number of normative legal acts [2, 3, 4, 5, 9]. However, the regulation of the use of the system of coordinates USC-2000 is indicated only in several legislative acts [7, 8].

It should be noted that in the Law of Ukraine № 353- XIV "On topographic and geodetic surveying and cartographic activity" the system of coordinates USC2000 is not mentioned. Only by the Resolution of the Cabinet of Ministers of Ukraine No 646 "Particular issues of the implementation of part 1 of Article 12 of the Law of Ukraine "Ontopographic and geodetic and cartographic activity"" specifies article 12 of the above-mentioned law.

Issues concerning the referential coordinate system USC-2000 were also considered by domestic scientists, namely: Zaets I. considered the use of this system [1] , the question of the use of several coordinate systems at the same time was studied by Kubakh S. and Chernyaga P. [10], the problems of using USC-2000 in the construction of hydraulic structures were studied by Kostetska Y., Zvyagina M., Melnik D. [6].

The purpose of the article is the coverage of some issues regarding the use of the USC-2000 coordinate system in force on land legislation that may arise when used in conjunction with the SC-63, namely the possible exceedances of the norms 
for the free transfer of land plots to citizens in the transition to a single state coordinate system .

Main material. According to Article 121 of the Land Code of Ukraine, citizens of Ukraine have the right to transfer free of charge land plots from the lands of state or communal property in the following amounts :

For the private agricultural farming - no more than 2.0 hectares;

for the construction and maintenance of a residential building, commercial buildings and structures (private plot) in villages - no more than 0,25 hectares ;

for gardening - no more than 0,12 hectares $^{2}[5]$.

That is, in the case of free privatization of land plots, executive bodies, local government bodies and the State Geocodist's administration may issue permits for the development of land-use documentation for land plots of the maximum permitted area.

Guided by such permissions, legal and physical persons who are executors of land management work, form new land with an appropriate area. This rafo g topogeodetic survey and transfer of land boundaries in nature (on ground) is held in the coordinates system SC-63.

It is in this system that the coordinates of the land plots registered in the State Land Cadastre are displayed.

It is worth recalling that the coordinate basis for the implementation of works on land management is the State Geodetic Reference System of Coordinates USC2000 [7] , that is, in order to comply with land management regulations, the current legislation requires the transfer of coordinates of land plots from SC-63 to the system USC-2000.

In addition, in accordance with the Resolution of the Cabinet of Ministers of Ukraine "Some issues of the implementation of part 1 of Article 12 of the Law of Ukraine " On topographic and geodetic and cartographic activity ", USC-2000 is used as a single coordinate system [8]. But such a conversion, because the system USC2000 is based on other than SC-63 reference ellipsoid, not only will change th ARE directional angles of lines and coordinates, but areas of land.

\footnotetext{
${ }^{2}$ For the purposes of the article, the authors selected rules for the free transfer of land plots of three intended purposes.
} 
To investigate such distortions, the authors designed three model land plots in the coordinate system SC-63 with the maximum allowable area in accordance with the norms of free transfer for the management of a personal farm (2,0000 hectares), for the construction and maintenance of residential buildings, household buildings and structures (farm plots) in villages ( 0,2500 hectares) and forgardening respectively $(0,1200$ hectares) . Subsequently, using the standard functions of the licensed Digitals software (Figure 1), the coordinates of each of the land plots from the SC-63 system in the USC-2000 were revised within the three selected administrative units.

For the purpose of visual representation, the coordinates of the first point of the listed land plots in USC-2000 were given the coordinates of the first point of land in the system SC-63.

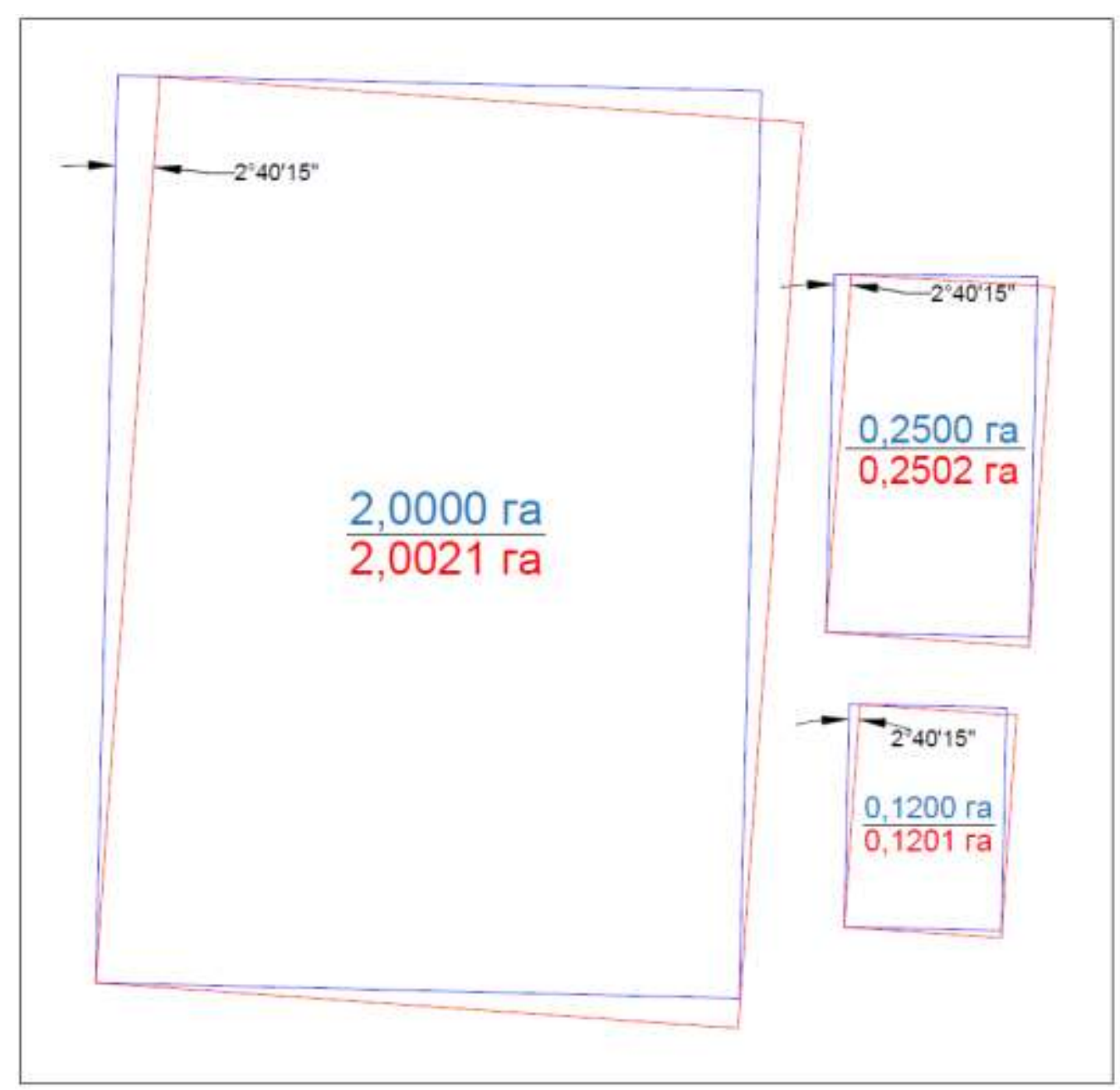

Fig . 1. Comparison of the location and area of land in the coordinate systems of the SC-63 and USC-2000 within the Malovilshansca village council of the Bila Tserkva district of the Kyiv region 
For example, when converting the coordinates of three model land plots, their area is increased by $21 \mathrm{~m}^{2}, 2 \mathrm{~m}^{2}$ and $1 \mathrm{~m}^{2}$ respectively, within the boundaries of the Malovilshansca village council of the Bila Tserkva district of the Kyiv region (Fig. 1).

When converting the coordinates of identical land plots within Obukhiv City Council of Obukhiv district of Kyiv region, the area of land plots varies by $12 \mathrm{~m}^{2}$, $1 \mathrm{~m}^{2}$ and $1 \mathrm{~m}^{2}$ (Fig. 2).

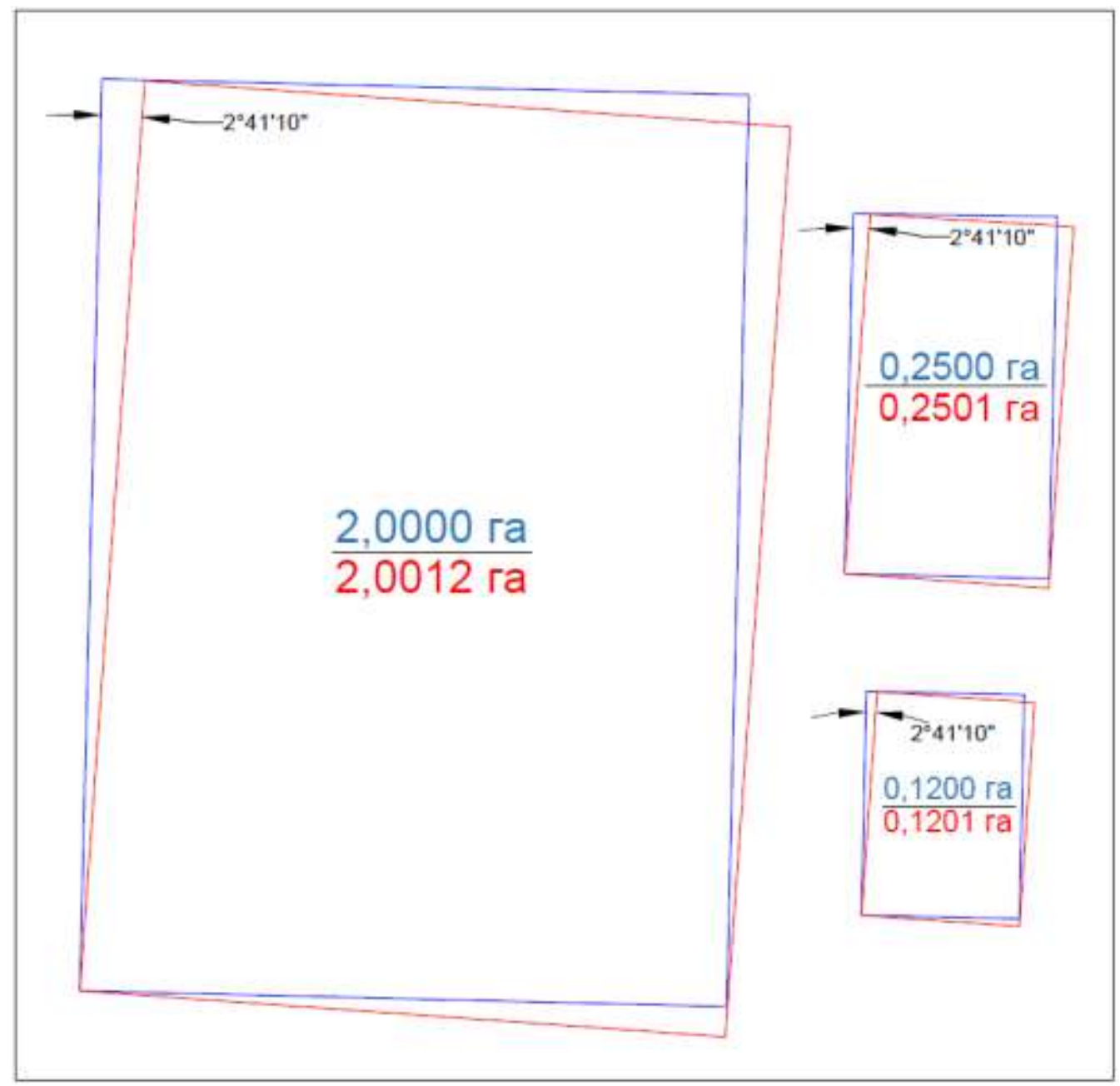

Fig. 2. Comparison of the location and area of land in the coordinate systems of the SC-63 and USC-2000 within the Obukhiv City Council of the Obukhiv district of the Kyiv region

Also in terms of the model coordinate land within the settlment council Bilyaivsky district of Odessa region, the area of land changed to $13 \mathrm{~m}^{2}, 2 \mathrm{~m}^{2}$ and $1 \mathrm{~m}^{2}$ (Fig. 3). 


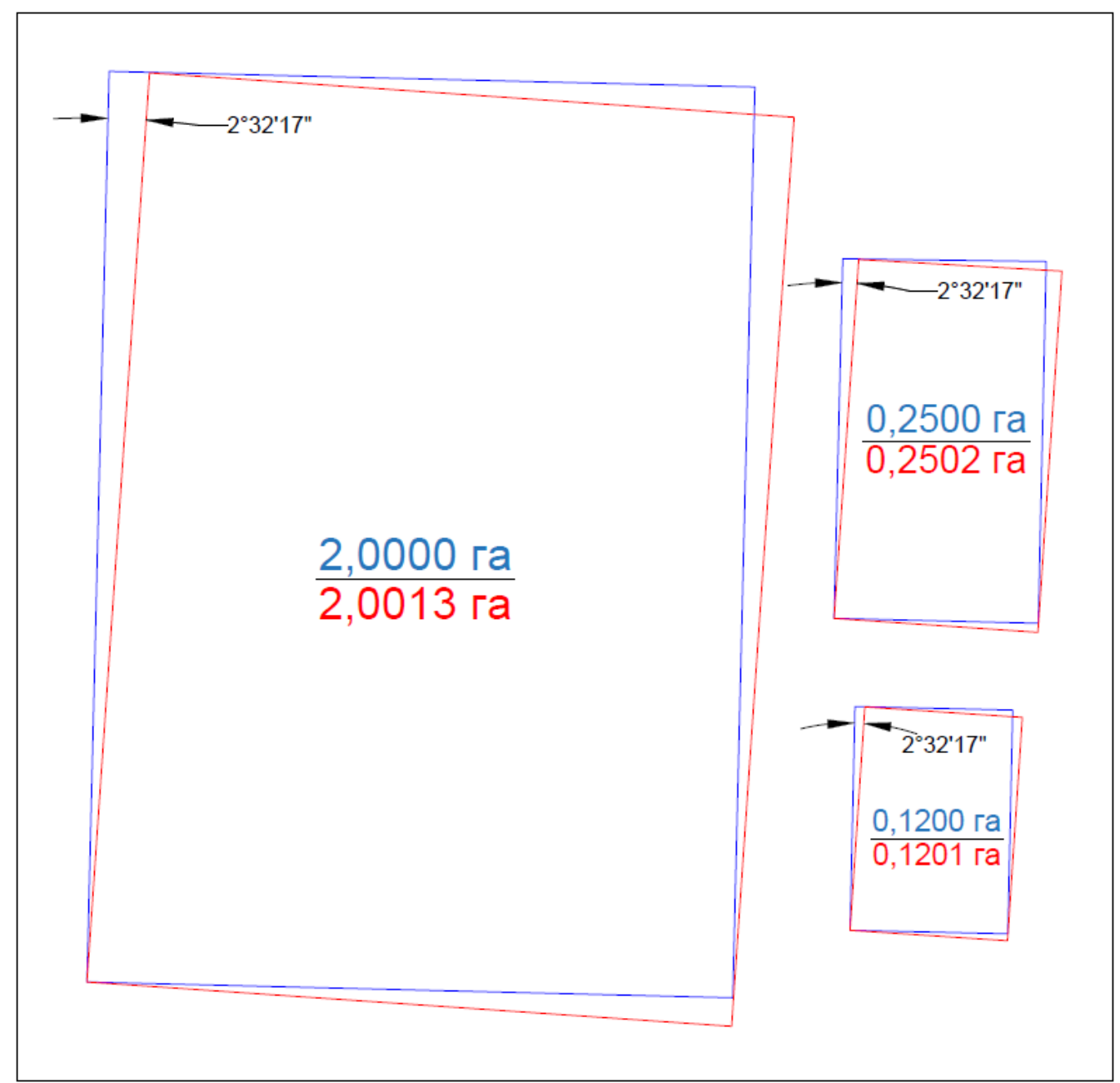

Fig. 3. Comparison of the location and area of land in the coordinate systems of the SC-63 and USC-2000 within the boundaries of the Khlibodar Settlement Council of the Bilyaivsky District of the Odesa region

The conversion of the coordinates of the aforementioned land plots was carried out using the standard functions of the licensed Digitals software (Figure 4).

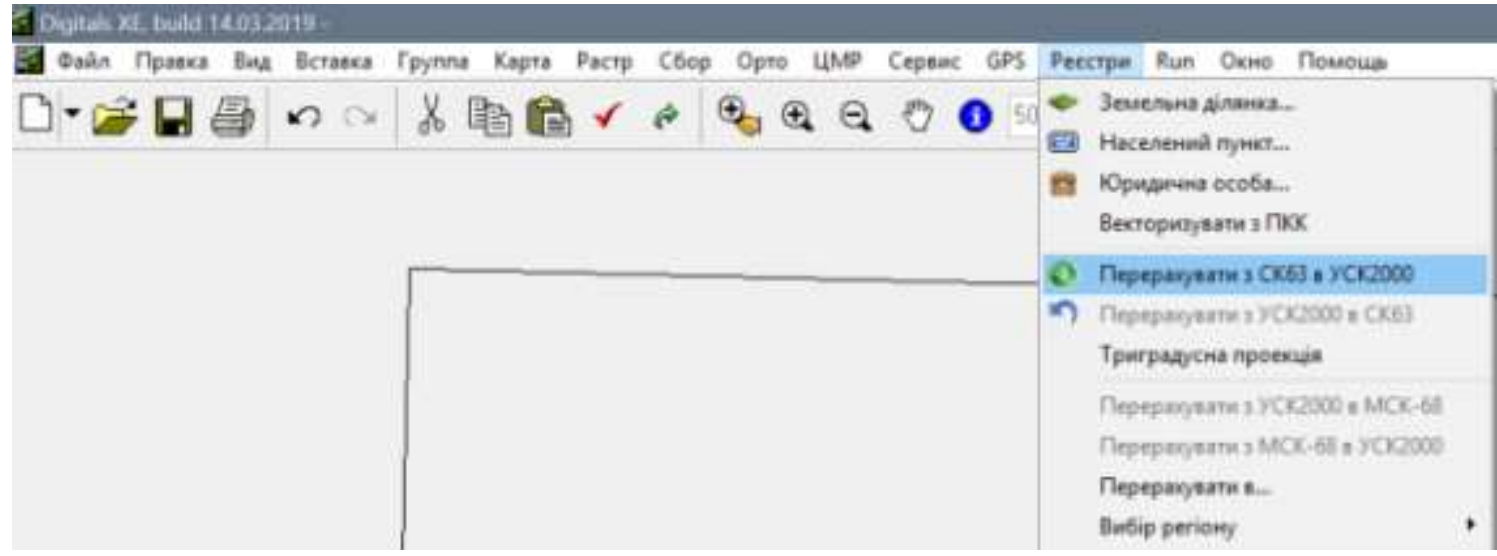

Fig. 4. Display of functions for converting coordinates into Digitals software. 
Such changes in areas are the result of the fact that USC-2000 is formed from ITRS/ITRF2000. For the reference ellipsoid in the specified system adopted referent ellipsoid KrasovSCogo , the parameters of which somewhat different from the parameters adopted for the coordinate system SC-63, based on the SC-42.

Conclusion. Changes or distortions in squares, lines or angles are obvious when moving from one coordinate system to another if they are based on ellipsoid referents with different parameters.

However, it should be noted that the compliance of the USC-2000 with the land legislation, and in particular the exceeding of the area of established norms for the free transfer of land plots by citizens in modern conditions, in the transition to legally established unified systems and coordinates USC-2000, requires further consideration and resolution, for example, by clarification of legislation.

\section{References}

1. Zaiets I. (2014) Osnovni zasady vykorystannia heodezychnoi referentnoi systemy koordynat USK-2000 dlia zabezpechennia vedennia Derzhavnoho zemelnoho kadastru [Main foundations of using geodetic referent coordinate system USC-2000 for the purpose of State land cadtre]. Suchasni dosiahnennia heodezychnoi nauky ta vyrobnytstva. Lviv. Vol. I (27). P. 9-11.

2. The Verkhovna Rada of Ukraine (2011). The Law of Ukraine "On State land cadastre". Available at: http://zakon.rada.gov.ua/laws/show/3613-17\#n369.

3. The Verkhovna Rada of Ukraine (2003). The Law of Ukraine "On land management". Available at: http://zakon.rada.gov.ua/laws/show/858-15.

4. The Verkhovna Rada of Ukraine (1998). The Law of Ukraine «On topographic and geodetic and cartographic activity». Available at: https://zakon.rada.gov.ua/laws/show/353-14.

5. The Verkhovna Rada of Ukraine (2002), The Law of Ukraine "Land Code of Ukraine", Vidomosti Verkhovnoi Rady Ukrainy, vol. 3-4, p. 27.

6. Kostetska Ya.M., Zviahina M.S., Melnyk D.M. (2014) Aktualni problemy zastosuvannia systemy koordynat USK-2000 v heodezychnomu 
zabezpechenni kadastrovykh robit i hidrotekhnichnoho budivnytstva [Actual problems of using the system of coordinates USK-2000 in geodetic supply of cadastral works and hydraulic engineering]. Visnyk heodezii ta kartohrafii. Kyiv. № 5 (92). P. 5-9.

7. Ministry of Agripolicy and production of Ukraine (2016) Resolution of the Cabinet of Ministers of Ukraine № 509 «On Approval of the Procedure for the Use of the State Geodetic Reference System of the USC-2000 Coordinate System in the Implementation of Land Management Works». Available at: https://zakon.rada.gov.ua/laws/show/z1646-16.

8. Ministry of Agripolicy and production of Ukraine (2013) Resolution of the Cabinet of Ministers of Ukraine № 646 «Particular issues of the implementation of part one of Article 12 of the Law of Ukraine "On topographic and geodetic and cartographic activity"». Available at: https://zakon.rada.gov.ua/laws/show/646-2013$\% \mathrm{D} 0 \% \mathrm{BF}$.

9. Cabinet of Ministers of Ukraine (2012), "Resolution of the Cabinet of Ministers of Ukraine № 1051 «On Approval of the Procedure for the State Land Cadastre». Available at: https://zakon.rada.gov.ua/laws/show/1051-2012-\%D0\%BF.

10. Cherniaha P., Kubakh S. (2010) Perevahy ta nedoliky riznykh system koordynat ta heodezychnykh proektsii pid chas vedennia zemelnoho kadastru. Suchasni dosiahnennia heodezychnoi nauky ta vyrobnytstva [Advantages and disadvantages of different coordinate systems and geodesic projections during land cadastre]. Lviv. Vol. II (20). P. 62-66.

$* * *$

Аврамчук Б.О., Патіюк О.О.

ДЕЯКІ ПИТАННЯ ВІДПОВІДНОСТІ СИСТЕМИ КООРДИНАТ УСК-2000 ЗЕМЕЛЬНОМУ ЗАКОНОДАВСТВУ

Координатною основою при здійсненні робіт із землеустрою є Державна геодезична референцна система координат УСК-2000. Проте, як показує практика землевпорядних робіт, публічна інформачія з Державного земельного кадастру відображається в системі координат 1963 року (СК-63).

При цььому, у більшості випадків перерахунок площ між вищзезазначеними координатними системами призводить до зміни площ земельних ділянок. 
Тому важливо висвітлити деякі питання щзодо використання системи координат USC-2000 з чинним земельним законодавством, яке може виникнути при використанні спільно з SC-63, а саме можливе перевищення норм для вільного переказу. земельних ділянок громадянам при переході до єдиної державної системи координат.

Для дослідження таких спотворень авторами було запроектовано три модельні земельні ділянки в системі координат СК-63 максимально допустимою площею згідно з нормами безоплатної передачі для ведення особистого селянського господарства (2,0000 га), для будівнищтва $і$ обслуговування жилого будинку, господарських будівель $i$ споруд (присадибна ділянка) у селах (0,2500 га) та для ведення садівнищтва відповідно (0,1200 га). Після цьього, використовуючи стандартні функиії лічензованого програмного забезпечення Digitals, було здійснено перерахунок координат кожної із земельних ділянок із системи СК-63 в УСК-2000 в межах трьох вибраних адміністративно-територіальних одинииях.

3 цุіллю наочного відображення, координатам першої точки перерахованих земельних ділянок в УСК-2000 були надані значення координат першої точки земельних ділянок в системі СК-63.

Зміни або спотворення в площуах, довжинах ліній чи кутах є очевидним явщщем при переході з однієї системи координат до іншої, якщо вони базуються на референт-еліпсоїдах з різними параметрами.

Проте, варто зазначити, щуо відповідність використання УСК-2000 земельному законодавству, а особливо перевищення площ встановлених норм безоплатної передачі земельних ділянок громадянах в сучасних умовах при переході до законодавчо встановленої єдиної системи координат УСК-2000, потребує подальшого розгляду та вирішення, наприклад, иляхом уточнення законодавства.

Ключові слова: Земельний Кодекс, норми безоплатної приватизації, референцна система координат, СК-63, УСК-2000.

$* * *$

Аврамчук Б.О., Патиюк О.О.

НЕКОТОРЫЕ ВОПРОСЫ СООТВЕТСТВИЯ СИСТЕМЫ КООРДИНАТ УСК2000 ЗЕМЕЛЬНОМУ ЗАКОНОДАТЕЛЬСТВУ

Координатной основой при осуществлении работ по землеустройству является Государственная геодезическая референцная система координат УСК-2000. Однако, как показывает практика землеустроительных работ, публичная информация из Государственного земельного кадастра отображсается в системе координат 1963 (СК-63). 
При этом, в большинстве случаев пересчет площуадей между вышеупомянутыми координатными системами приводит к изменению площадей земельных участков.

Поэтому важно осветить некоторые вопросы использования системы координат USC-2000 с действующим земельным законодательством, которое может возникнуть при использовании совместно с SC-63, а именно возможно превышение норм для свободного перевода. земельных участков гражданам при переходе кединой государственной системы координат.

Для исследования таких искажений авторами было запроектировано три модельные земельные участки в системе координат СК-63 максимально допустимой площуадью в соответствии с нормами бесплатной передачи для ведения личного крестьянского хозяйства (2,0000 га), для строительства и обслуживания жилого дома, хозяйственных зданий и сооружений (приусадебный участок) в селах (0,2500 га) и для ведения садоводства соответственно (0,1200 га). После этого, используя стандартные функции лищензированного программного обеспечения Digitals, был осуществлен пересчет координат каждой из земельных участков из системы СК-63 в УСК-2000 в пределах трех выюранных административно-территориальных единицах.

С иелью наглядного отображения, координатам первой точки перечисленньхх земельных участков в УСК-2000 были предоставлены значения координат первой точки земельных участков в системе СК-63.

Изменения или искажения в площуадях, длинах линий или углам очевидно явлением при переходе из одной системы координат к другой, если они базируются на референсэллипсоида с различныли параметрами.

Однако, стоит отметить, что соответствие использования УСК-2000 земельному законодательству, а особенно превымение площуадей установленных норм бесплатной передачи земельных участков гражданам в современных условиях при переходе к законодательно установленной единой системьл координат УСК-2000, требует дальнейтего рассмотрения и решения, например, путем уточнения законодательства.

Ключевые слова: Земельный Кодекс, нормы бесплатной приватизации, референцная система координат, СК-63, УСК-2000. 